\title{
Florida Fresh: Tomatoes ${ }^{1}$
}

Claudia Peñuela and Jennifer Hillan ${ }^{2}$

\section{Nutrition Facts}

Florida's Tomatoes are:

$\checkmark$ High in vitamin C. Vitamin C helps to heal cuts and keeps teeth and gums healthy.

$\checkmark$ A good source of vitamin A. Vitamin A aids in normal vision, healthy skin, and protects against infections.

$\checkmark$ High in lycopene. Studies show that heat-processed tomatoes such as tomato sauce and tomato paste make the lycopene available for absorption by the body. Lycopene, which acts as an antioxidant, helps protect the body's cells from oxygen damage and may reduce the risk of heart disease and certain cancers.

$\checkmark$ A good source of potassium. Potassium helps to control blood pressure. $\checkmark$ Naturally free of cholesterol and fat, and low in calories and sodium.

\begin{tabular}{|c|c|}
\hline \multicolumn{2}{|l|}{ Amount Per Serving } \\
\hline \multirow{2}{*}{\multicolumn{2}{|c|}{$\begin{array}{c}\text { Calories from Fat } 3 \\
\% \text { Daily Value } \\
\end{array}$}} \\
\hline & \\
\hline Total Fat $0 \mathrm{~g}$ & $1 \%$ \\
\hline Saturated Fat $0 \mathrm{~g}$ & $0 \%$ \\
\hline \multicolumn{2}{|l|}{ Trans Fat } \\
\hline Cholesterol 0mg & $0 \%$ \\
\hline Sodium $9 \mathrm{mg}$ & $0 \%$ \\
\hline Total Carbohydrate $7 \mathrm{~g}$ & $2 \%$ \\
\hline Dietary Fiber $2 g$ & $9 \%$ \\
\hline \multicolumn{2}{|l|}{ Sugars $5 \mathrm{~g}$} \\
\hline \multicolumn{2}{|l|}{ Protein $2 \mathrm{~g}$} \\
\hline $30 \% \cdot$ Vitamin C & $38 \%$ \\
\hline Calcium $\quad 2 \% \cdot$ Iron & $3 \%$ \\
\hline \multicolumn{2}{|c|}{$\begin{array}{l}\text { "Percent Daily Values are based on a } 2,000 \text { calorie diet. } \\
\text { Your daily values may be higher or lower depending on } \\
\text { your calorie needs. }\end{array}$} \\
\hline () www.NutritionData.com & \\
\hline
\end{tabular}

\section{Why Buy Locally?}

The U.S. Department of Agriculture (USDA) estimates that the average farmers' market produce travels about $\mathbf{5 0}$ miles to its destination, compared to $\mathbf{2 , 0 0 0}$ miles for supermarket produce.

Buy locally and get these benefits:

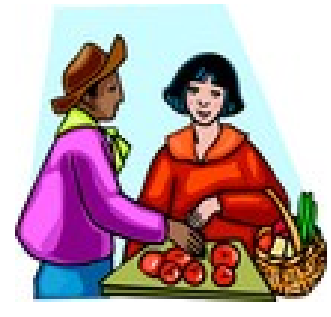

$>$ Freshness and good nutrition. Fruits and vegetables harvested in their peak have better flavor and nutritional characteristics.

$>$ Social/cultural. Helps the community to be aware of the importance of agriculture.

Environmental. Protects the natural resources such as green space, wildlife, water, air, and soil.

Economic. Promotes local labor force.

\section{Where are Florida's tomatoes harvested?}

The majority of Florida's tomatoes are harvested in Central and South Florida; Gadsden County in Northwest Florida is an important producer as well. Varieties of tomatoes are cherry, plum, grape, and slicing (beefsteak). All varieties can be used in salads, but plum tomato is also used in cooked dishes.

1. This document is FCS8674, one of a series of the Department of Family, Youth and Community Sciences, Florida Cooperative Extension Service, Institute of Food and Agricultural Sciences, University of Florida. First published: June 2001. Revised: August 2009. Visit the EDIS Web site at http://edis.ifas.ufl.edu.

2. Claudia Peñuela, nutrition assistant-EFNEP, Department of Family, Youth and Community Sciences; Institute of Food and Agricultural Sciences; Jennifer Hillan, assistant in., College of Medicine; University of Florida; Gainesville, FL 32611.

The Institute of Food and Agricultural Sciences (IFAS) is an Equal Opportunity Institution authorized to provide research, educational information and other services only to individuals and institutions that function with non-discrimination with respect to race, creed, color, religion, age, disability, sex, sexual orientation, marital status, national origin, political opinions or affiliations. U.S. Department of Agriculture, Cooperative Extension Service, University of Florida, IFAS, Florida A. \& M. University Cooperative Extension Program, and Boards of County Commissioners Cooperating. Millie Ferrer-Chancy, Interim Dean. 


\section{When can you buy Florida tomatoes?}

You can buy Florida tomatoes from September through June. This is ten months out of the year!

\begin{tabular}{|l|l|l|l|l|l|l|l|l|l|l|l|}
\hline JAN & FEB & MAR & APR & MAY & JUN & JUL & AUG & SEP & OCT & NOV & DEC \\
\hline
\end{tabular}

\section{Select}

$\checkmark$ Unrefrigerated tomatoes because they have more flavor.

$\checkmark$ Fresh tomatoes. If you buy unripe tomatoes, put them in a warm area or in a brown paper bag to help them ripen.

$\checkmark$ Tomatoes that are slightly soft without bruises and cracks.

$\checkmark$ Tomatoes that have soft spots, sunken areas, or mold are usually decayed and should not be selected.

\section{Florida Fresh Tomatoes: From Market to Table}

\section{Gazpacho}

8 large tomatoes, peeled

1 large cucumber, peeled, seeded, and finely diced

1 large green bell pepper, finely chopped

1 medium-size red onion, minced

3 Tbsp red wine vinegar

1 Tbsp olive oil

3 Tbsp lemon juice

$2 \frac{1}{2}$ Tbsp chopped fresh parsley or 2 tsp dried basil

Salt and pepper to taste

Hot pepper sauce to taste

\section{Yield: $\mathbf{6}$ Servings Time $\mathbf{2 0}$ minutes; leave chilled}

1. Core the tomatoes and squeeze out the seeds. Coarsely chop half of the tomatoes and purée the other half in a blender or food processor.

2. Combine the purée and chopped tomatoes in a large mixing bowl.

3. Add the remaining ingredients.

4. Cover and refrigerate for at least an hour before serving.

5. Serve chilled; garnish with herbed croutons if desired.

*Nutrition info per serving: Calories: 90 cal; Total Fat 3g; Sodium 65mg; Total Carbohydrates 14g; Fiber 4g; Protein 3g; Vitamin A 45\%; Vitamin C 100\%; Calcium 4\%; Iron 6\%* Vitamin A, Vitamin C, Calcium and Iron listed as $\%$ of daily value based on 2,000 calories.

Adapted from: $\underline{\text { www.fruitsandveggiesmatter.gov/downloads/explore recipe cards.pdf }}$

\section{Provençal Roasted Florida Tomatoes}

4 large ripe tomatoes, sliced $1 / 4$-inch thick

$1 / 8$ cup grated Romano cheese

$1 / 2$ cup fresh breadcrumbs

1 garlic clove, minced

2 sprigs fresh parsley, chopped

Salt and pepper to taste

$1 / 2$ tsp dried oregano

Olive oil or nonstick olive oil spray

\section{Yield: 4 Servings Time $\mathbf{3 0 - 4 0}$ minutes; serve warm}

1. Preheat oven to $400^{\circ} \mathrm{F}$.

2. Coat a shallow baking dish with cooking spray or olive oil. Place tomato slices close together in prepared baking dish. Sprinkle with cheese, breadcrumbs, garlic, parsley, salt, pepper, and oregano.

3. Drizzle lightly with olive oil or spray with nonstick olive oil spray.

4. Bake for 20 minutes in preheated oven or until top is lightly toasted.

Nutrition info per serving: Calories: 110 cal; Total Fat 2g; Cholesterol 2mg; Sodium 180mg; Total Carbohydrates 17g; Protein 4g. Good source of Vitamin C. 